\title{
Nutritional parameters of steers receiving different levels of sunflower crushed in partial replacement of soybean meal
}

\author{
HELLEN L. LIMA ${ }^{1}$, RAFAEL H.T.B. DE GOES ${ }^{1}$, SARA L.N. CERILO ${ }^{1}$, \\ EUCLIDES R. DE OLIVEIRA ${ }^{1}$, MARIA G.M. GRESSLER ${ }^{1}$ and KELLY C.S. BRABES ${ }^{2}$ \\ ${ }^{1}$ Universidade Federal da Grande Dourados/UFGD, Faculdade de Ciências Agrárias, \\ Rodovia Dourados/Itahum, Km 12, Caixa Postal 533, 79804-940 Dourados, MS, Brasil \\ ${ }^{2}$ Universidade Federal da Grande Dourados/UFGD, Faculdade de Engenharia, \\ Rodovia Dourados/Itahum, Km 12, Caixa Postal 533, 79804-940 Dourados, MS, Brasil \\ Manuscript received on January 16, 2012; accepted for publication on November 23, 2012
}

\begin{abstract}
To evaluate of the sunflower crushed in nutritional parameters in steers, supplemented at pasture, we used four steers in $4 \times 4$ Latin square design. The supplements were provided in $6 \mathrm{~g} / \mathrm{kg}$ of body weight/animal/day, consisting of sunflower crushed, corn, soybean meal and mineral. All the supplements was isonitrogenous and soybean meal was replaced in $0,20,40$, and $60 \%$ for sunflower crushed. The determination of ruminal $\mathrm{pH}$ and ammonia was at $0,2,4,6$ and $8 \mathrm{~h}$. after feeding and for short-chain fatty acids it was collected at 0 and $6 \mathrm{~h}$. post-feeding. The dry matter intake was not affected $(P>0.05)$ by inclusion of sunflower crushed (mean=6.59 kg/day). There was no significant effect $(P>0.05)$ for $\mathrm{pH}$ for the inclusion of sunflower crushed (mean=6.41). For contents of ruminal $\mathrm{NH}_{3}-\mathrm{N}$ was a significant effect $(P<0.05)$ only for collection time, and ammonia peaks occurred between 2 and $4 \mathrm{~h}$ after feeding, with values of 22.56 and $21.40 \mathrm{mg} / \mathrm{dL}$. The total concentration of short chain fatty acids and the $\mathrm{C} 2: \mathrm{C} 3$ ratio was reduced in 9.6 and $15.43 \%$. The ruminal degradability of NDF was not affected by the supplements. The supplementation with sunflower crushed to beef steers grazing, in partial replacement of soybean meal did not alter nutrition parameters.
\end{abstract}

Key words: fatty acid, ammonia, $\mathrm{pH}$, by-product, supplementation.

\section{INTRODUCTION}

The use of crushed oilseed, in ruminant feeding has attracted interest from many producers, which in some cases provides this food without knowing basic information about limiting consumption. The sunflower crushed by cold pressing for vegetable oil extraction, is an alternative source of nutrients, containing 24 to $33.3 \mathrm{~g} / 100 \mathrm{~g}$ of $\mathrm{CP}, 79 \mathrm{~g} / 100 \mathrm{~g}$

Correspondence to: Rafael Henrique de Tonissi

e Buschinelli de Goes

E-mail: rafaelgoes@ufgd.edu.br /

rafael.buschinelligoes@gmail.com of TDN and of $16.5 \mathrm{~g} / 100 \mathrm{~g}$ of fat (Goes et al. 2008, 2010, Domingues et al. 2010, Oliveira et al. 2007), but shows extreme variation in lipid content (6-30\%), resembling the characteristics of whole seeds due to the content of polyunsaturated lipids

The use of lipids sources in ruminants can cause reduction in the consumption of dry matter, by the quality of oil contained in the grain rich in polyunsaturated fatty acids, which are biohydrogenaded by rumen microorganisms, resulting in greater energy intake for the animal (Marin et al. 2010). A major problem with the addition of lipids in ruminants 
diets, is the change in ruminal fermentation, with degradation of structural carbohydrates reduction in the by $50 \%$ or more (Jenkins 1993).

The energetic and protein supplementation is necessary when expects improve a daily gain, for this it's necessary to know what influences the absorption of ingested nutrients. Ruminal parameters such as short chain fatty acids, $\mathrm{pH}$ and ammonia nitrogen help explain the digestibility, voluntary dry matter intake, performance and rate of degradation. The intake is related to reduction of digestibility, ruminal $\mathrm{pH}$ and the responses to the supplement offered. The presence of non-structural carbohydrates at high levels reduces the $\mathrm{pH}$ and the growth of cellulolytic bacteria, reducing intake and digestibility.

The rumen ecosystem to be complex brings great benefit to the animal, processing food with low biological value and transforming in nutrients with high nutritional value. For this the rumen must maintain optimal physical and chemical conditions such as temperature $\left(39^{\circ} \mathrm{C}\right), \mathrm{pH}(5.7$ to 7.0$)$ and $\mathrm{NH}_{3}-\mathrm{N}$. The ruminal $\mathrm{pH}$ is directly related to the final products of fermentation and microorganisms growth rate.

The objective of this study was to evaluate the effects of supplementation with sunflower crushed in substitution of soybean meal on intake, ruminal degradability in steers kept on pasture.

\section{MATERIALS AND METHODS}

The experiment was conducted in the sector of Ruminant Nutrition, of Universidade Federal da Grande Dourados (UFGD), located in Dourados/MS, between October and November 2009 (Table I), with a trial period of 52 days (four periods of 13 days).

TABLE I

Maximum (Tmax) and minimum (Tmin) temperature, maximum relative humidity (URmax) and minimum (URmin) and precipitation (Prec) for the city of DouradosMS during the months of October and November 2009.

\begin{tabular}{cccccc}
\hline Month & $\begin{array}{c}\text { Tmax } \\
\left({ }^{\circ} \mathbf{C}\right)\end{array}$ & $\begin{array}{c}\text { Tmin } \\
\left({ }^{\circ} \mathbf{C}\right)\end{array}$ & $\begin{array}{c}\text { URmax } \\
(\mathbf{\%})\end{array}$ & $\begin{array}{c}\text { Urmin } \\
(\mathbf{\%})\end{array}$ & $\begin{array}{c}\text { Prec } \\
(\mathbf{m m})\end{array}$ \\
\hline October & 29.76 & 18.64 & 93.61 & 33.75 & 11.59 \\
November & 33.40 & 21.17 & 92.50 & 47.00 & 5.00 \\
\hline
\end{tabular}

We used four crossbred steers, castrated, with 18 months of age and average weight of $285 \mathrm{~kg}$, fitted with rumen cannula, wormed with Ivermectin (1\%) at the beginning of the experiment. All animals were kept in individual paddocks of $B$. brizantha cv Marandu in 4x4 latin square design.

The concentrate was supplied daily in the trough, the amount of $6 \mathrm{~g} / \mathrm{kg}$ of body weight/day in the morning until 10 a.m. so as not to interfere in forage intake. At the end of each experimental period the animals were rotated in the paddocks and supplements were adjusted according to the weight obtained.

The supplements were isonitrogenous with $28 \%$ of crude protein, and crushed sunflower replaced the soybean meal in 0, 20, 40 and 60\% (Table II). The chemical composition of the ingredients used is presented in Table III.

\section{TABLE II}

Share the ingredients ( $\mathrm{g} / \mathrm{kg}$ as fed) and chemical composition of concentrates (g/100 g Dry Matter - DM).

\begin{tabular}{ccccc}
\hline Ingredients & $\mathbf{C 0 0}^{\#}$ & $\mathbf{C 2 0}^{\#}$ & $\mathbf{C 4 0}^{\#}$ & $\mathbf{C 6 0}^{\#}$ \\
\hline Corn & 426 & 357 & 287 & 218 \\
Soybean meal & 524 & 419 & 315 & 210 \\
Sunflower & -- & 174 & 348 & 522 \\
crushed & & & & 50 \\
Mineral & 50 & 50 & 50 \\
\hline Parameters & Chemical composition (g/100g of DM) \\
\hline DM & 91.51 & 87.46 & 87.97 & 91.03 \\
CP & 29.35 & 27.87 & 27.91 & 27.46 \\
EE & 3.68 & 5.65 & 8.82 & 11.00 \\
NDF & 26.98 & 29.32 & 30.44 & 32.48 \\
ADF & 5.51 & 13.86 & 17.16 & 18.73 \\
TDN* & 85.12 & 82.00 & 78.38 & 76.00 \\
MM & 3.25 & 3.19 & 4.30 & 5.28 \\
\hline
\end{tabular}

*\%NDT $=9,6134+0,829$ DMS. Capelle et al. (2001).

\# $\mathrm{C} 00=$ Concentrate without sunflower crushed; $\mathrm{C} 20=$ Concentrate with $20 \%$ of soybean meal replaced for sunflower crushed; $\mathrm{C} 40=$ Concentrate with $40 \%$ of soybean meal replaced for sunflower crushed; C60 $=$ Concentrate with $60 \%$ of soybean meal replaced for sunflower crushed.

$\mathrm{DM}=$ dry matter, $\mathrm{CP}=$ crude protein, $\mathrm{EE}=$ ether extract, $\mathrm{NDF}$ $=$ neutral detergent fiber, $\mathrm{ADF}=$ acid detergent fiber, $\mathrm{TDN}=$ total digestible nutrients and $\mathrm{MM}=$ mineral matter. 
The experimental area had two hectares, divided into four paddocks, separated by electric fence with drinking and feeding troughs. The pasture of $B$. brizantha cv Marandu was established in 2008 through a of integrated crop / livestock system, after planting corn.

On the first day of each experimental period, it was determined the total availability of dry matter forage by cut at ground level of 10 areas delimited by square metal $\left(0.25 \mathrm{~m}^{2}\right)$ randomly within each paddock. The collection of forage consumed by animals (extrusa) occurred in the $13^{\text {th }}$ day of each experimental period, by ruminal emptying. Prior to collecting the animals were fasted for $12 \mathrm{~h}$ to ensure total forage intake.

The sample collection of extrusa was held at 8 a.m., the rumen was emptied and dried with cotton cloth. After that, the animals returned in their respective paddocks and grazed for 30 minutes, after graze the material ingested was removed. Were collected $400 \mathrm{~g}$ of extrusa, which was stored in plastic bags, labeled, and transported in a coolbox (to avoid undesirable fermentation and loss of moisture) to the Animal Nutrition Laboratory/FCA/UFGD.

TABLE III

Chemical composition of ingredients used in concentrated for steers.

\begin{tabular}{lccccccc}
\hline Ingredients & DM* & $\mathbf{C P}^{*}$ & EE* $^{*}$ & NDF* $^{*}$ & ADF* $^{*}$ & MM* $^{*}$ & IVDDM* \\
\hline Soybean Meal & 85.64 & 50.99 & 6.71 & 34.14 & 20.08 & 9.68 & 95.40 \\
Corn & 87.86 & 11.68 & 3.28 & 13.93 & 5.43 & 1.70 & 98.80 \\
Sunflower crushed & 95.05 & 30.93 & 16.76 & 42.69 & 31.27 & 4.72 & 64.54 \\
Mineral & 96.31 & - & - & - & - & - & - \\
\hline
\end{tabular}

$\mathrm{DM}=$ dry matter, $\mathrm{CP}=$ crude protein, $\mathrm{EE}=$ ether extract, $\mathrm{NDF}=$ neutral detergent fiber, $\mathrm{ADF}=$ acid detergent fiber, $\mathrm{MM}=$ mineral matter and IVDMM $=$ in vitro dry matter digestibility.

* \% Dry matter.

In the Laboratory, the samples were analyzed for dry matter (DM), crude protein $(\mathrm{CP})$, ether extract (EE), and Ash (CZ), according to techniques described by AOAC (2006); neutral detergent fiber (NDF) and acid (ADF), lignin (LIG) by Van Soest et al. (1991). The in vitro digestibility of dry matter (IVDMD) was determined according to the method described by Tilley and Terry (1963), using the in vitro incubator, by Tecnal ${ }^{\circledR}$ (TE-150), with modification of the bag material used (made with TNT $-100 \mathrm{~g} / \mathrm{m}^{2}$ ), as suggested by Casali et al. (2008).

The TDN of the forage and concentrate were estimated by equations proposed by Capelle et al. (2001). TDN content of forage was calculated based on the ADF, according to equation: $\% \mathrm{TDN}=$ 74.49 to $0.5635 * \mathrm{ADF}\left(\mathrm{r}^{2}=0.82\right)$ and TDN content of the concentrate was estimated based on in vitro dry matter (DMD), where\% TDN $=9.6134+0.829$ * DMD $\left(r^{2}=0.98\right)$. The total carbohydrates (TC) and non-structural carbohydrates (NSC) equations estimated as TC $=100 \%-(\% \mathrm{CP}+\% \mathrm{EE}+\% \mathrm{MM})$ and $\mathrm{CNE}=\% \mathrm{NDF}-\mathrm{CT}$ by Sniffen et al. (1992).

The dry matter intake was determined based on the relationship between an external (chromium oxide, $\mathrm{Cr}_{2} \mathrm{O}_{3}$ ) and an internal (iADF) marker, where from the second day of the experiment was introduced in the rumen of animals via the rumen cannula, $10 \mathrm{~g}$ of $\mathrm{Cr}_{2} \mathrm{O}_{3}$ twice a day at 8 a.m. and 5 p.m., for a 10 days period, five days of adaptation and five days of collection (Soares et al. 2003).

Feces samples were collected directly from the rectum of the animals at the same times for the supply of chromium oxide and packed in plastic bags properly identified and sent to the Laboratory of Animal Nutrition and frozen at $-10{ }^{\circ} \mathrm{C}$. At the end of each period was carried out a sample by animal, removing a sample of each animal in each paddock for a period. Analyses of chromium in the feces were 
performed by atomic absorption spectrophotometry according to Williams et al. (1962).

For the determination of fecal dry matter production was used the formula: $g$ DM feces excreted per day $=\left(100 \times \mathrm{Cr}_{2} \mathrm{O}_{3}\right.$ supplied $) /(\%$ of $\mathrm{Cr}_{2} \mathrm{O}_{3}$ in fecal DM). The indigestible ADF was used to estimate forage intake, determined according to procedure described by Penning and Johnson (1983), adapted by Detmann et al. (2001) based on in situ degradability, for $144 \mathrm{~h}$.

The dry matter intake was determined using the equation: $\mathrm{DMI}=\{[(\mathrm{EF} \times \mathrm{CIFZ})-\mathrm{IS}] / \mathrm{CIFO}\}$ + CMSS, Where, DMI $=$ dry matter intake $(\mathrm{kg} /$ day $)$ $\mathrm{EF}=$ fecal excretion $(\mathrm{kg} /$ day $) ; \mathrm{CIFZ}=$ concentration of the indicator present in the feces $(\mathrm{kg} / \mathrm{kg}), \mathrm{IS}=$ indicator present in the supplement (kg/day); CIFO $=$ concentration of the indicator present in the forage $(\mathrm{kg} / \mathrm{kg}), \mathrm{CMSS}=$ consumption dry matter of supplement ( $\mathrm{kg}$ /day).

In a 12-day trial were introduced directly into the rumen, the 8 a.m., the amount of concentrate corresponding to the intake of animals. The collection of rumen fluid for the determination of $\mathrm{pH}$ and ammonia nitrogen $\left(\mathrm{NH}_{3}-\mathrm{N}\right)$ were performed at the interface liquid / solid of rumen filtered triple layer of gauze, before delivery of the concentrate (0h) and 2, 4, 6 and $8 \mathrm{~h}$ after feeding.

The $\mathrm{pH}$ determination was performed immediately after collection, in $40 \mathrm{~mL}$ of ruminal fluid and measured with the use of portable digital peagameter. For the determination of ammonia nitrogen was collected $40 \mathrm{~mL}$ of ruminal fluid, which has been preserved with $1 \mathrm{~mL}$ of $1: 1 \mathrm{HCl}$, to prevent fermentation and volatilization of ammonia, being frozen at $-20{ }^{\circ} \mathrm{C}$.

To determine the concentration of ruminal $\mathrm{NH}_{3}-\mathrm{N}$, the ruminal fluid was thawed and centrifuged at 3,000 rpm for $10 \mathrm{~min}$. The supernatant was collected to quantify the concentration of ammonia nitrogen by the Micro-Kjedhal method, and distillation with $\mathrm{KOH} 2 \mathrm{~N}$, using a $2 \%$ boric acid and titration with $0.005 \mathrm{~N}$ hydrochloric acid (Campos et al. 2004).
To determine the concentrations of short chain fatty acids (SCFA) $10 \mathrm{~mL}$ of rumen fluid was retired before and 6 hours after animal feeding, which was preserved in $10 \mathrm{~mL}$ of formic acid 85\% PA. The samples were stored in plastic containers, labeled and sent to the Laboratory of Bromatology by the Escola Superior de Agricultura "Luiz de Queiroz", where they were centrifuged at $10,000 \mathrm{~g}\left({ }^{\circ} \mathrm{C}\right)$ for 50 minutes, then analyzed by liquid chromatography- gas (Hewlett Packard 5890 Series II GC column packed WHP $1.8 \mathrm{~m}$, with oven temperature of $113{ }^{\circ} \mathrm{C}$ (isotherm), equipped with integrator (Hewlett Packard 3396 Series II Integrator) and auto sampler (Hewlett Packard 6890 Series Injector) temperature $160{ }^{\circ} \mathrm{C}$, and detector type FID at $190{ }^{\circ} \mathrm{C}$. The carrier gas used was nitrogen. The internal standard used was 2-metilbutíric acid being added to each tube for reading chromatograph, $100 \mathrm{~mL}$ internal standard $500 \mu \mathrm{L}$ sample and $500 \mu \mathrm{L}$ formic acid. A mixture of volatile fatty acids known concentration was used as external standard for calibration of the integrator (Campos et al. 2004).

To determine the degradability of DM and NDF of the $B$. brizantha cv Marandu was used bags $\left(5.0 \times 5.0 \mathrm{~cm}\right.$ ) made of TNT of $100 \mathrm{~g} / \mathrm{m}^{2}$ (Casali et al. 2008). All samples were prepared following the recommendations of Nocek (1988). The samples were ground in sieves of $5 \mathrm{~mm}$, weighed in the amount of $0.5 \mathrm{~g}$, in a relationship of $20 \mathrm{mg} / \mathrm{cm}^{2}$. All bags were sealed and placed at $65^{\circ} \mathrm{C}$ for $24 \mathrm{~h}$ and then weighed.

The tulle bags measuring $15 \times 30 \mathrm{~cm}$, and containing $100 \mathrm{~g}$ weight, were introduced directly into the rumen, in decreasing order of $96,48,24$, $18,6,3 \mathrm{~h}$, in triplicate animal / incubation time. At time $0 \mathrm{~h}$ the bags were pre-incubated in a container with water. The bags were removed all at once and washed in running water. The remaining waste from incubations were dried in a forced air oven at $65{ }^{\circ} \mathrm{C}$ for $48 \mathrm{~h}$ and stored for analysis, in order to determine the variables under study.

To estimate the potential degradability (PD) was used asymptotic first-order model proposed by 
Orskov and McDonald (1979): PD = a + b (1-e $\left.\mathrm{e}^{-\mathrm{ct}}\right)$, where PD is the potential degradability of food; "a" is the soluble fraction, " $b$ ", the potentially degradable fraction; "c", which would be the rate of degradation of fraction " $b$ " and " $t$ " is incubation time in hours. The effective degradability (ED): $\mathrm{ED}=\mathrm{a}+[(\mathrm{b} * \mathrm{c})$ $/(\mathrm{c}+\mathrm{K})]$, where $\mathrm{K}$ is the rate of passage from the rumen solids, defined here as $5.0 \% / \mathrm{h}$.

Statistical analysis was realized by the latin square design $4 \times 4$. The measurements of $\mathrm{pH}$, ruminal ammonia and short chain fatty acids were determined in a split plot arrangement. Analyses of variance and regression were performed by statistical package SAEG 9.1 (UFV 2007) and the averages compared by Tukey test at $5 \%$ probability.

\section{RESULTS AND DISCUSSION}

During the experimental period, the total available dry matter was 3,666.11 kg DM / ha and green dry matter availability was $2,999.52 \mathrm{~kg} /$ ha (Table IV), values similar to that obtained by Silva et al. (2009), who pointed out that animal selectivity to occur, the total dry matter, and green dry matter it's should be 4,500 kg DM/ha and 1,200 kg / ha.

TABLE IV

Total availability of dry matter (ATDM) of forage, availability of green dry matter (AGDM), percentages of steam, leaves, senescent material and forage high $(\mathrm{cm})$.

\begin{tabular}{lcccc}
\hline & \multicolumn{4}{c}{ Substitution levels (\%) } \\
\cline { 2 - 5 } & $\mathbf{0 0}$ & $\mathbf{2 0}$ & $\mathbf{4 0}$ & $\mathbf{6 0}$ \\
\hline ATDM (Ton DM/ha) & 2.53 & 2.55 & 5.58 & 3.32 \\
AGDM (Ton Green DM/ha) & 2.52 & 2.54 & 5.58 & 3.13 \\
Stem (\%) & 31.18 & 32.58 & 38.43 & 34.61 \\
Leaves (\%) & 50.64 & 45.02 & 51.14 & 55.18 \\
Senescenet material (\%) & 18.16 & 22.38 & 10.41 & 10.20 \\
High (cm) & 20.52 & 31.72 & 36.45 & 34.82 \\
\hline
\end{tabular}

The pasture had an average of $15.88 \% \mathrm{CP}$ (Table V), over 7\% CP, of Van Soest (1994), cites as the limit for the reduction of dry matter intake. When have high levels of fiber forage, voluntary intake is reduced, since the dry matter digestibility is low, causing a greater retention time, promoting physical limitations of the intake. In this work the pasture had high dry matter digestibility (average $79.10 \%$ ), which may explain the values found for dry matter intake of animals (Table VI).

The performance of beef cattle can be affect by the energy: protein ratio of forage (TDN: CP), according to Moore et al. (1999), when this ratio is greater than 7.0 indicates protein deficiency in relation to the energy available, resulting in decreased forage intake, which was not observed in this experiment, where the relationship TDN: CP forage ingested by the animals had an average of 5.04.

TABLE V

Chemical composition of extruded, in dry matter base (\%DM) of Brachiaria brizanta cv Marandu, grazed.

\begin{tabular}{|c|c|c|c|c|c|}
\hline \multirow[b]{2}{*}{$(\% \mathrm{DM})^{\mathrm{ns}}$} & \multicolumn{4}{|c|}{ Substitution levels (\%) } & \multirow[b]{2}{*}{ CV $(\%)$} \\
\hline & 00 & 20 & 40 & 60 & \\
\hline $\mathrm{DM}$ & 15.86 & 16.57 & 15.50 & 15.62 & 13.98 \\
\hline $\mathrm{CP}$ & 13.19 & 15.67 & 16.52 & 15.51 & 18.09 \\
\hline NDF & 76.83 & 76.63 & 77.01 & 76.80 & 4.76 \\
\hline $\mathrm{ADF}$ & 34.72 & 34.18 & 33.66 & 36.11 & 21.98 \\
\hline LIG & 5.59 & 7.18 & 7.77 & 7.21 & 24.8 \\
\hline $\mathrm{TDN}+++$ & 79.53 & 70.93 & 76.06 & 74.22 & 8.80 \\
\hline IVDM & 84.35 & 73.97 & 80.16 & 77.93 & 8.80 \\
\hline ASH & 2.87 & 4.12 & 1.93 & 3.30 & 71.40 \\
\hline TDN:CP & 6.02 & 4.53 & 4.60 & 5.02 & - \\
\hline
\end{tabular}

*\%TDN = 9,6134+0,829DMS. Capelle et al., (2001).

$\mathrm{DM}=$ dry matter, $\mathrm{CP}=$ crude protein, $\mathrm{EE}=$ ether extract, $\mathrm{NDF}$ $=$ neutral detergent fiber, $\mathrm{ADF}=$ acid detergent fiber, $\mathrm{MM}=$ mineral matter and IVDMM = in vitro dry matter digestibility. ns $=$ no significant.

The total dry matter intake had an average of $6.59 \mathrm{~kg} /$ day $(23.1 \mathrm{~g} / \mathrm{kg}$ body weight).Valadares Filho et al. (2010), for animals in the same category, presented a $24.9 \mathrm{~g} / \mathrm{kg}$ body weight similar to our work. Domingues et al. (2010), replacing cottonseed meal by sunflower crushed at $0,25,50,75$ and $100 \%$, found reduction the dry matter intake by $13.4 \%$.

The NDF intake ( $\mathrm{kg} /$ day) and CP intake $(\mathrm{kg} /$ day), has changed, by the chemical composition of the supplements (Table II). The sunflower crushed has high levels of NDF and ADF (Goes et al. 2010), 
and large amounts of lignin contained mainly in the shell of the grain, which could explain the high consumption of animal NDF. Even with the intake higher for the substitution levels of 20 and $40 \%$, the total dry matter intake was not affect.

The intake of crude protein was influenced by the levels studied, with a quadratic behavior $(\mathrm{Y}=$ $\left.-0.0001+0.0091 x+0.66 x^{2}, r^{2}=0.99\right)$. The animals that received higher levels of supplementation with sunflower crushed had a higher intake of CP (Table VI). Van Soest (1994) presented a minimum intake of crude protein in the diet of ruminants $70 \mathrm{~g} / \mathrm{kg}$; less than this would be below the nitrogen required by rumen bacteria, thus changing the dry matter intake. In this work the values of total intake of dietary CP was higher than this level $(108,112,122$ and $128 \mathrm{~g} / \mathrm{kg}$ ), for the substitution levels of 00,20 , 40 and $60 \%$, respectively.

\section{TABLE VI}

Dry matter intake of forage (CMSF), supplement intake

(CMSS), total dry matter intake (CMST), neutral detergent fiber intake (NDF Cons) and crude protein intake (CP Cons ), expressed in $\mathrm{kg} / \mathrm{day}$ and \% CP diet.

\begin{tabular}{lcccccc}
\hline \multicolumn{7}{c}{ Substitution levels (\%) } \\
\hline & $\mathbf{0 0}$ & $\mathbf{2 0}$ & $\mathbf{4 0}$ & $\mathbf{6 0}$ & $\mathbf{C V}(\%)$ & $\mathbf{S}$ \\
\hline CMSF (kg/d) & 4.53 & 5.23 & 4.93 & 4.16 & 44.58 & $\mathrm{Ns}$ \\
CMSF (\%BW) & 1.59 & 1.84 & 1.73 & 1.46 & - & - \\
CMSup (kg/d) & 1.56 & 1.81 & 2.05 & 2.09 & 20.77 & Ns \\
CMSup (\%BW) & 0.55 & 0.64 & 0.72 & 0.73 & - & - \\
CMST (kg/d) & 6.1 & 7.05 & 6.98 & 6.24 & 28.07 & Ns \\
CMST (\%BW) & 2.14 & 2.47 & 2.45 & 2.19 & - & - \\
ConsNDF (kg/d) & $1.64^{\mathrm{b}}$ & $1.91^{\mathrm{a}}$ & $1.95^{\mathrm{a}}$ & $1.69^{\mathrm{b}}$ & 6.96 & $*$ \\
ConsCP (kg/d) & $0.66^{\mathrm{c}}$ & $0.79^{\mathrm{b}}$ & $0.85^{\mathrm{a}}$ & $0.80^{\mathrm{b}}$ & 2.57 & $*$ \\
Dietary CP (\%) & 10.8 & 11.2 & 12.2 & 12.8 & - & - \\
\hline
\end{tabular}

$\mathrm{S}=$ significant, $\mathrm{ns}=$ not significant by Tukey test at $5 \%(\mathrm{P}>0.05)$.

* Means followed by different letters differ by Tukey test at $5 \%(\mathrm{P}<0.05)$.

The oil in the sunflower crushed has, polyunsaturated fatty acids, which are biohydrogenated by bacteria and protozoa, resulting in higher energy intake (Marín et al. 2010), thus decreasing DM intake. Unsaturated fatty acids have toxic effects on gram-positive microorganisms (Van Soest 1994), as fribrolytic bacteria, which may cause problems related to the decrease in the degradation of the fiber in the diet (Marin et al. 2010), by decrease in passage rate and dry matter intake. Although the sunflower crushed contain high levels of unsaturated fatty acids, the inclusion of supplements did not alter the dry matter intake of the animals or the degradability of NDF (Table VII).

Even with a slight variation between the kinetic parameters of degradation for DM and NDF fractions, they did not change the potential and effective degradability of pasture, which had an average of $64.88,35.25$ and $37.68 \%$ and $60.78 \%$, respectively.

The partial replacement of soybean meal by sunflower crushed did not alter ruminal $\mathrm{pH}$ of the animals, with a mean of 6.41 (Table VIII). The value found is higher than the 6.2 limit, proposed by Russell and Wilson (1996), as the threshold so that does not reduce the synthesis and inhibition of microbial degradation of NDF. The average $\mathrm{pH}$ value reinforces reports that diets with a predominance of forage must have neutral $\mathrm{pH}$. Domingues et al. (2010), working with different inclusion levels of sunflower crushed instead of cottonseed meal, found $\mathrm{pH}$ values of $6.2,6.4,6.5$ and 6.5 for the treatments with addition of sunflower cake of 0,25 , 50 and $75 \%$, respectively.

High concentrations of ruminal ammonia results in greater net absorption of ammonia nitrogen $\left(\mathrm{NH}_{3}-\mathrm{N}\right)$ by rumen walls, conversion into urea and consequent losses through urinary excretion (Assis et al. 2004). The concentration of ruminal $\mathrm{NH}_{3}-\mathrm{N}$, had effect for time of collection $(\mathrm{P}>$ $0.05)$. The highest peaks occurred between 2 and 4 hours after supplementation, with values of 22.56 and 21.41 (Table VIII), like the work of Domingues et al. (2010). Perhaps this relationship may be due to the metabolism of rumen microorganisms with maximum microbial activity occurring at $\mathrm{pH}$ 6.5.

The mean concentrations of $\mathrm{NH}_{3}-\mathrm{N}$ in rumen fluid were above the minimum required by Detmann et al. (2007) for maximum microbial growth and 
TABLE VII

Potential degradability (PD) and effective degradability (ED) of dry matter and neutral detergent fiber, to $B$. brizantha cv Marandu, in steers supplemented with sunflower crushed in a partial replacement for soybean meal.

\begin{tabular}{|c|c|c|c|c|c|c|c|}
\hline \multirow[b]{2}{*}{ Parameters* } & \multicolumn{5}{|c|}{ Substitution levels (\%) } & \multirow[b]{2}{*}{ Average } & \multirow[b]{2}{*}{$S$} \\
\hline & 00 & 20 & 40 & 60 & CV (\%) & & \\
\hline \multicolumn{8}{|l|}{ Dry matter } \\
\hline $\mathrm{PD}$ & 67.04 & 61.58 & 65.88 & 65.05 & 18.05 & $64.88 \pm 2.35$ & ns \\
\hline ED & 35.25 & 35.93 & 35.27 & 34.53 & 14.57 & $35.25 \pm 0.57$ & ns \\
\hline$r^{2}$ & 0.87 & 0.90 & 0.80 & 0.77 & - & - & - \\
\hline \multicolumn{8}{|c|}{ Neutral Detergent Fiber } \\
\hline $\mathrm{DP}$ & 63.33 & 62.36 & 56.91 & 60.53 & 16.37 & $60.78 \pm 2.83$ & ns \\
\hline $\mathrm{DE}$ & 40.03 & 42.77 & 35.41 & 32.52 & 19.54 & $37.68 \pm 4.59$ & ns \\
\hline$r^{2}$ & 0.83 & 0.85 & 0.73 & 0.76 & - & - & - \\
\hline
\end{tabular}

$\mathrm{S}=$ significant, $\mathrm{ns}=$ not significant $(\mathrm{P}>0.05)$.

* $\mathrm{PD}=$ potential degradability; $\mathrm{ED}=$ effective degradability at a rate of $5 \% / \mathrm{h}$.

TABLE VIII

Averages of $\mathrm{pH}$ and $\mathrm{NH}_{3}-\mathrm{N}$ ruminal, for steers supplemented with sunflower crushed in a partial replacement of soybean meal, and its coefficient of variation.

\begin{tabular}{|c|c|c|c|c|c|c|}
\hline \multirow{2}{*}{$\begin{array}{l}\text { Substitution } \\
\text { levels }(\%)\end{array}$} & \multirow[b]{2}{*}{$\mathbf{0}$} & \multicolumn{4}{|c|}{ Hours } & \multirow[b]{2}{*}{ Averages } \\
\hline & & 2 & 4 & 6 & 8 & \\
\hline \multicolumn{7}{|c|}{$p H$} \\
\hline 00 & 6.45 & 6.25 & 6.33 & 6.39 & 6.21 & $6.33^{\mathrm{a}}$ \\
\hline 20 & 6.44 & 6.49 & 6.39 & 6.46 & 6.26 & $6.41^{\mathrm{a}}$ \\
\hline 40 & 6.47 & 6.26 & 6.36 & 6.63 & 6.46 & $6.43^{\mathrm{a}}$ \\
\hline 60 & 6.59 & 6.31 & 6.56 & 6.54 & 6.57 & $6.51^{\mathrm{a}}$ \\
\hline Average & $6.48^{\mathrm{a}}$ & $6.33^{\mathrm{a}}$ & $6.41^{\mathrm{a}}$ & $6.50^{\mathrm{a}}$ & $6.37^{\mathrm{a}}$ & 6.42 \\
\hline \multicolumn{7}{|l|}{$\mathrm{CV}(\%)$} \\
\hline \multicolumn{7}{|c|}{$\mathbf{N}-\mathbf{N H}_{3}(\mathrm{mg} / \mathrm{dL})$} \\
\hline 00 & 13.18 & 20.03 & 20.34 & 18.64 & 19.72 & $18.38^{\mathrm{a}}$ \\
\hline 20 & 16.73 & 25.07 & 24.98 & 16.76 & 21.14 & $20.93^{\mathrm{a}}$ \\
\hline 40 & 15.47 & 23.83 & 17.53 & 17.59 & 17.26 & $18.34^{\mathrm{a}}$ \\
\hline 60 & 10.65 & 21.32 & 22.78 & 18.54 & 17.07 & $18.07^{\mathrm{a}}$ \\
\hline Average & $14.00^{\mathrm{b}}$ & $22.56^{\mathrm{a}}$ & $21.41^{\mathrm{a}}$ & $17.88^{\mathrm{ab}}$ & $18.80^{\mathrm{ab}}$ & 18.93 \\
\hline CV (\%) & \multicolumn{6}{|c|}{31.56} \\
\hline
\end{tabular}

$\mathrm{S}=$ significant, $\mathrm{ns}=$ not significant $(\mathrm{P}>0.05)$.

$* \mathrm{PD}=$ potential degradability; $\mathrm{ED}=$ effective degradability at a rate of $5 \% / \mathrm{h}$.

ruminal digestion of $10 \mathrm{mg} / \mathrm{dL}$, occuring more appropriate growth medium the availability of nitrogen for microbial anabolism. To maximizing dry matter intake, the concentrations should be above $20 \mathrm{mg} / \mathrm{dL}$, which only occurred between 2 and $4 \mathrm{~h}$ after supplementation.
Domingues et al. (2010), found $\mathrm{NH}_{3}-\mathrm{N}$ values ranging from 3.1 to $14.5 \mathrm{mg} / \mathrm{dL}$ in ruminal fluid inferior to that found in this study (mean of 18.93 $\mathrm{mg} / \mathrm{dL}$ ). The high $\mathrm{NH}_{3}-\mathrm{N}$, are due to the solubility provided by the supplement, according to Beran et al. (2007), the sunflower crushed is characterized 
by widely be degradable, and its protein content less degradable than $10 \%$. Goes et al. (2008) found average colonization time of $6 \mathrm{~h}$ to degradation in the rumen of sunflower crushed. The reduction of ammonia concentration after four hours of feeding may be due to the increased efficiency of microorganisms.

The acids propionic, isobutyric, butyric, isovaleric and valeric, were not affected by the inclusion of sunflower crushed (Table IX), with averages of $21.27,4.81,12.50,1.92,2.75 \mathrm{mmol} / \mathrm{mL}$.

The supplementation reduced the concentration of acetic acid after 6 hours. The ratio of shortchain fatty acids can be changed depending on the type of food and $\mathrm{pH}$, since the cellulolytic bacteria, gram $(+)$, cannot tolerate the acidic conditions of the environment and reduce the production of acetate, the main product of fiber fermentation, causing a consequent decrease in the acetate: propionate (Chalupa et al. 1986).

The total concentration of short chain fatty acids and the acetate: propionate $(\mathrm{C} 2$ : $\mathrm{C} 3)$ ratio, was reduced by 9.6 and $15.43 \%$, six hours after supplementation. The pool of fatty acids after meals, is from the action of microorganisms when they incorporate dietary sugars and returns for the environment fatty acids, the main factor to the decrease in $\mathrm{pH}$ in these periods. The effect of association between the production of short chain fatty acids and the release of ammonia in the rumen compartment alters the stability of the ruminal $\mathrm{pH}$, and changes in the magnitude of these factors can occur when oil included in the diet (Loor et al. 2002) what did not happen in this work.

The reduction ratio of $\mathrm{C} 2$ : $\mathrm{C} 3$, is due to decreased production of acetic acid, possibly due a presence of high-concentrate diet with roughage: concentrate ratio of $71.4: 28.6$. The decrease of the ratio of acetate and $\mathrm{C} 2$ : $\mathrm{C} 3$ has been explained by the tendency of amylolytic and fibrolytic bacteria produce more acetate and propionate.

The production of valeric acid and isoacid (isobutyric and isovaleric) are derived from the
TABLE IX

Concentration of short chain fatty acids $(\mathrm{mmol} / \mathrm{mL})$, and the acetate:propionate $(\mathrm{C} 2: \mathrm{C} 3)$ ratio, of steers supplemented with sunflower crushed in a partial replacement for soybean meal.

\begin{tabular}{|c|c|c|c|c|c|c|}
\hline \multicolumn{7}{|c|}{ Substitution levels (\%) } \\
\hline \multicolumn{7}{|c|}{ Acetic acid } \\
\hline Hour & 00 & 20 & 40 & 60 & Average $^{\#}$ & $\mathrm{CV}(\%)$ \\
\hline 0 & 90.78 & 102.61 & 100.08 & 93.52 & $96.74^{\mathrm{a}}$ & \\
\hline 6 & 86.67 & 82.79 & 84.06 & 79.89 & $83.35^{\mathrm{b}}$ & 14.69 \\
\hline Average & 88.78 & 92.70 & 92.07 & 86.71 & & \\
\hline \multicolumn{7}{|c|}{ Propionic acid } \\
\hline Hour & 00 & 20 & 40 & 60 & Average & $\mathrm{CV}(\%)$ \\
\hline 0 & 19.67 & 21.63 & 21.54 & 21.38 & $21.06^{\mathrm{a}}$ & \\
\hline 6 & 21.81 & 20.63 & 22.04 & 21.38 & $21.47^{\mathrm{a}}$ & 13.46 \\
\hline Average & 20.74 & 21.12 & 21.79 & 21.38 & & \\
\hline \multicolumn{7}{|c|}{ Isobutiric acid } \\
\hline Hour & 00 & 20 & 40 & 60 & Average & $\mathrm{CV}(\%)$ \\
\hline 0 & 4.71 & 4.93 & 5.29 & 4.64 & $4.89 \mathrm{a}$ & \\
\hline 6 & 4.78 & 4.80 & 4.82 & 4.52 & $4.73 \mathrm{a}$ & 7.52 \\
\hline Average & 4.75 & 4.86 & 5.05 & 4.57 & & \\
\hline \multicolumn{7}{|c|}{ Isovaleric acid } \\
\hline Hour & 00 & 20 & 40 & 60 & Average & $\mathrm{CV}(\%)$ \\
\hline 0 & 1.88 & 1.87 & 1.95 & 2.00 & $1.93 \mathrm{a}$ & 6.78 \\
\hline 6 & 1.97 & 1.71 & 1.89 & 2.03 & $1.90 \mathrm{a}$ & \\
\hline Average & 1.93 & 1.79 & 1.92 & 2.01 & & \\
\hline \multicolumn{7}{|c|}{ Valeric acid } \\
\hline Hour & 00 & 20 & 40 & 60 & Average & $\mathrm{CV}(\%)$ \\
\hline 0 & 2.67 & 2.75 & 2.79 & 2.80 & $2.75 \mathrm{a}$ & 7.83 \\
\hline 6 & 2.73 & 2.72 & 2.73 & 2.82 & $2.75 \mathrm{a}$ & \\
\hline Average & 2.70 & 2.73 & 2.76 & 2.81 & & \\
\hline \multicolumn{7}{|c|}{ Total short chain fatty acid } \\
\hline Hour & 00 & 20 & 40 & 60 & Average $^{\#}$ & $\mathrm{CV}(\%)$ \\
\hline 0 & 132.63 & 147.46 & 144.81 & 136.85 & $140.44 a$ & 13.56 \\
\hline 6 & 131.38 & 125.22 & 128.26 & 122.87 & $126.93 b$ & \\
\hline Average & 132.01 & 136.33 & 136.53 & 129.87 & & \\
\hline \multicolumn{7}{|c|}{$\mathrm{C} 2: \mathrm{C3}$} \\
\hline Hour & 00 & 20 & 40 & 60 & Average $^{\#}$ & $\mathrm{CV}(\%)$ \\
\hline 0 & 4.62 & 4.76 & 4.65 & 4.37 & $4.60 \mathrm{a}$ & 7.11 \\
\hline 6 & 3.97 & 4.02 & 3.81 & 3.73 & $3.89 b$ & \\
\hline Average & 4.30 & 4.39 & 4.23 & 4.05 & & \\
\hline
\end{tabular}

\# Means followed by lowercase letters in the column do not differ by Tukey test at $5 \%$ significance level $(\mathrm{P}<0.05)$.

fermentation of protein. Ruminal concentrations of isobutyric and isovaleric are indicative of amino acid fermentation, which in high concentrations accumulate SCFA, the main factor reducing the $\mathrm{pH}$. Ruminants fed with diets rich in forage, the 
rumen microbial population usually converts carbohydrates fermented in 60 to $70 \%$ acetic acid, 18 to $22 \%$ propionic acid, 13 to $16 \%$ butyric acid and 2 to $4 \%$ of valeric acid.

\section{CONCLUSION}

The partial replacement of soybean meal by sunflower cake can be made up to $60 \%$ for beef cattle, without altering the intake forage and total dry matter, and the ruminal parameters.

\section{ACKNOWLEDGMENTS}

The Conselho Nacional de Desenvolvimento Científico e Tecnológico (CNPq) and Fundação ao Apoio ao Desenvolvimento do Ensino Ciência e Tecnologia do Mato Grosso do Sul (Fundect) for financially supporting this work, the Universidade Federal da Grande Dourados (UFGD), Coordenação de Aperfeiçoamento de Pessoal de Nível Superior (CAPES) and CNPq by scholarships granted. To Prof. Gian Paulo Giovanni Freschi and Felipe Manfroi Fortunato for their assistance in conduction of laboratory tests for determining the levels of chromium.

\section{RESUMO}

Avaliou-se a torta de girassol em suplementos, sobre os parâmetros ruminais em novilhos mantidos a pasto. Foram utilizados quatro bovinos, em quadrado latino $4 \times 4$. Os suplementos avaliados foram fornecidos na quantidade de $6 \mathrm{~g} / \mathrm{kg}$ de peso corporal/animal/dia e constituídos de torta de girassol, em substituição ao farelo de soja nas proporções de $0,20,40$, e $60 \%$. A determinação do $\mathrm{pH}$ e da amônia ruminal ocorreram nos tempos de 0, 2, 4, 6 e 8 horas pós-suplementação, e a dos ácidos graxos de cadeia curta 0 e 6 horas após o fornecimento dos suplementos. O consumo de matéria seca não foi influenciado $(\mathrm{P}>0,05)$ pelos níveis de inclusão de torta de girassol apresentando média de $6,59 \mathrm{~kg} /$ dia. Não ocorreu efeito $(\mathrm{P}>0,05)$, para o pH em função da inclusão da torta de girassol, sendo a média de 6,41. Para os teores de $\mathrm{N}-\mathrm{NH}_{3}$ ruminal ocorreu efeito $(\mathrm{P}<0,05)$, somente para tempo de coleta, onde os picos de amônia ocorreram entre 2 e 4 horas após o fornecimento do suplemento, com valores de 22,56 e $21,40 \mathrm{mg} / \mathrm{dL}$. A concentração total de ácidos de cadeia curta e a relação C2:C3, foi reduzida em 9,6 e 15,43\%, seis horas após a suplementação. A degradabilidade ruminal da FDN não foi alterada pelos suplementos. A suplementação com torta de girassol para novilhos de corte em pastejo, em substituição parcial ao farelo de soja não altera os parâmetros nutricionais.

Palavras-chave: ácidos graxos, amônia, pH ruminal, coproduto, suplementação.

\section{REFERENCES}

Assis AJ. CAMPos JMS, QUEIROZ AC, VAladares Filho SC, EUCLYDES RF, LANA RP, MAGALHÃES ALR, MENDES Neto J And Mendonça SS. 2004. Citrus Pulp in Diets for Milking Cows. 2. Digestibility of Nutrients in Two Periods of Feces Collection and Rumen Fluid $\mathrm{pH}$ and Ammonia Nitrogen. R Bras Zootec 33(1): 251-257.

AOAC - Association of OfFicial AnAlytic Chemists. 2006. Official Methods of Analysis. $18^{\text {th }}$ ed., Arlington, V.A., AOAC International, $1422 \mathrm{p}$.

BERAN FHB, SILVA LDF, RIBEIRO ELA, ROCHA MA, EZEQUIEL JMB, Correa RA, CASTRO VS AND SILVA KCF. 2007. Evaluation of intestinal digestibility of different concentrate feeds using an in vitro three-step enzymatic procedure. R Bras Zootec 36: 130-137.

CAmpos FP, Nussio CMB And Nussio LG. 2004. Métodos de análise de alimentos. FEALQ, 135 p.

Capelle ER, Valadares Filho SC, Silva JFC and Cecon PR. 2001. Estimates of the Energy Value from Chemical Characteristics of the Feedstuffs. R Bras Zootec 30(6): 1837-1856.

Casali aO, Detmann E, Valadares Filho SC, Pereira JC, HenriQues LT, Freitas SG ANd Paulino MF. 2008. Influence of incubation time and particles size on indigestible compounds contents in cattle feeds and feces obtained by in situ procedures. R Bras Zootec 37(2): 335-342.

Chalupa W, Vecchiarelli B, Elser AE, Kronfeld DS, SKLAN D AND PALMQUIST DL. 1986. Ruminal fermentation in vivo as influenced by long-chain fatty acids. J D Sci 69(5): 1293-1301.

Detmann E, Cecon PR, Paulino MP, Valadares Filho SC, Henriques LT and Detmann KSC. 2007. Rumen variables evaluated through continuum mathematical functions. Pesq Agropec Bras 42(11): 1651-1657.

Detmann E, Paulino MF, Zervoudakis JT, Valadares FILHO SC, EUCLYDES RF, LANA RP AND QUEIROZ DS. 2001. Chromium and internal markers in intake determination by crossbred steers, supplemented at pasture. R Bras Zootec 30(5): 1600-1609. 
Domingues AR, Silva LDF, RibeIro ELA, CASTRo VS, BARBosa MAAF, MORI RM, VIEIRA MTL AND SILVA JAO. 2010. Intake, ruminal parameters and plasmatic urea concentration in beef cattle fed diets with different levels of sunflower cake in substitution to the cotton meal. Semina: Ci Agr 31(4): 1059-1070.

GoEs RHTB, SOUZA KA, PATUSSI RA, CORNELIO TC, OLIVEIRA ER AND BRABES KCS. 2010. In situ ruminal degradability of crambe, sunflower and soybean seeds and their byproducts in sheep feeding. Acta Sci Anim Sci 32: 271-277.

Goes RHTB, Tramontini RCM, Almeida GD, CARDim ST, Ribeiro J, Oliveira LA, MOROTTI F, Brabes KCS AND OLIVEIRA ER. 2008. Ruminal degradability of dry matter and crude protein of different by-products fed to steers. Rev Bras Saúde Prod Anim 9(4): 715-725.

JENKINS TC. 1993. Lipid metabolism in the rumen. J Dairy Sci 76: 3851-3863.

LOOR JJ, HeRBEIN JH AND JENKINS TC. 2002. Nutrient digestion, biohydrogenation, and fatty acid profiles in blood plasma and milk fat from lactating Holstein cows fed canola oil or canolamide. Anim Feed Sci Tech 97: 65-82.

MARÍn ALM, HERNÁNDEZ MP, AlBA LP AND CASTRO GG. 2010. Digestión de los Lípidos en los Rumiantes: Una Revisión. Interciencia 35(4): 240-246.

Moore JE, Brant MH, KunKLE WE AND Hopkins DI. 1999. Effects of supplementation on voluntary forage intake, diet digestibility, and animal performance. J Anim Sci 77(suppl 2): 122-135.

NOCEK JE. 1988. In situ and others methods to estimate ruminal protein and energy digestibility. J D Sci 71(8): 2051-2069.

Oliveira MDS, MOTA DA, BARBosa JC, STEIN M AND BorgONOVI F. 2007. Chemical bromatologic composition and in vitro ruminal digestibility of concentrates containing differents levels of sunflower quacker. Ci Ani Bras 8(4): 629-638.

ORSKOV ER AND MCDONALD J. 1979. The estimation of protein degradability in the rumen from incubation measurements weighted according to rate of passage. J Agric Sci New York 92(1): 499-503.
PENNING PD AND JoHnSON RH. 1983. The use of internal markers to estimate herbage digestibility and intake. 2 . Indigestible acid fiber detergent fiber. J Agric Sci 100(1): 133-138.

RUSSEL JB AND WILSON DB. 1996. Why are ruminal cellulolitic bacteria unable to digest cellulose at low pH? J Dairy Sci 79: 1503-1509.

Silva FF, SÁ JF, Schio AR, ITAVo LCV, Silva RR AND MATEUS RG. 2009. Grazing supplementation: availability and quality $\mathrm{x}$ supplementation levels $\mathrm{x}$ performance. $\mathrm{R}$ Bras Zootec 38(supl. especial): 371-389.

SNIFFEN CJ, O'CONNOR JD, VAN SOEST PJ, FoX DG AND RUSSELL JB. 1992. A net carbohydrate and protein system for evaluating cattle diets: II Carbohydrate and protein availability. J Anim Sci 70: 3562-3577.

SOARES JPG, BERCHIELLI TT AND AZEVEDO JÚNIOR MA. 2003. comparison of chromium oxide and total feces collection techniques on digestibility estimates by cattle. Ars Vet 19(3): 280-287.

TILlEY JMA AND TERRY RA. 1963. A two-stage technique for the in vitro digestion of forage crops. J Brith Grass Soc Oxford 18: 104-111.

UFV - UNIVERsidAde FEDERAL DE VIÇOSA. 2007. SAEG Sistema de análises estatísticas e genéticas. Versão 9.1. (manual do usuário), Viçosa, MG, 142 p.

VALADARES FILHO SC, MARCONDES MI, ChIZZOTTI ML AND PAULINO PVR. 2010. Exigências nutricionais de Zebuínos puros e cruzados BR-CORTE, $2^{\text {a }}$ ed., Universidade Federal de Viçosa, 193 p.

VAN Soest PJ. 1994. Nutritional ecology of the ruminant. $2^{\text {nd }}$ ed., Ithaca: Cornell University Press, $476 \mathrm{p}$.

VAN SOEST PJ, ROBERTSON JB AND LEWIS BA. 1991. Methods for dietary fiber, neutral detergent, and nonstarch polysaccharides in relation to animal nutrition. J Dairy Sci 74(10): 3583-3597.

Willians CH, DAVID DJ AND ILsmaA O. 1962. The determination of chromic oxide in feces samples by atomic absorption spectrophotometers. J Agric Sci 59(1): $381-385$ 